\title{
Role of Immunohistochemical Tests in Early Diagnosis of T-cell Lymphoma with Primary Oral Manifestations
}

\author{
ADRIAN MUICA ${ }^{1}$, GALAFTEON OLTEAN ${ }^{2 *}$, SIMONA MOCAN², EMOKE HORVATH ${ }^{1}$, VERONICA GROZESCU1, \\ LUCIA MARIA MUICA ${ }^{2}$, EDWIN SEVER BECHIR ${ }^{1}$, MAHMOUD ELSAAFIN ${ }^{1}$, MARIANA PACURAR ${ }^{1}$ \\ ${ }^{1}$ University of Medicine and Pharmacy, Dental Medicine Faculty, 38 Gheorghe Marinescu Str., 540142, Tirgu Mures, Romania \\ 2 Emergency Clinical Hospital Tirgu Mures, 50 Gheorghe Marinescu Str., 540136, Tirgu Mures, Romania
}

The immunohistochemistry investigations have an essential role in the establishment of the early diagnosis and in evaluating the management of T cell lymphoma disease with first localization in the oral-pharynx area. This study present the role of immunohistochemistry tests in the diagnosis of T cell lymphoma with first oral manifestation and detailed the case of a patient with T cell lymphoma located at the level of the palatine tonsils. Early diagnosis was followed by a treatment according to Protocol LSG 15 associated with bone marrow transplant, and the evolution being favorable.

Keywords: oral bleeding, immunohistochemistry investigations, T cell lymphoma, medullar transplant

According to the WHO classification, the most common tumors that develop in the oro-pharyngeal area are the epithelial cells. Although extremely rare, lymphomas are ranked 2 as the incidence at this level and the most common location is $70 \%$ at the level of Waldeyer ring [1,2]. Also, the most common lymphomas of the head and neck region are lymphomas with B cells. How ever, very rarely, variants of T-cell lymphomas, including the peripheral type, are encountered in the oral cavity and oro-pharynx $[2,3]$.

T-cell lymphoma belongs to a heterogeneous group of tumors belonging to non-Hodgkin lymphoma (NHL) [4]. It is characterized by a neoplastic proliferation of T cells with various clinical-pathological aspects [5]. The clinical manifestations have of different forms, from dysphagia, odynophagia, more or less abundant bleeding in the oral cavity, sometimes shortness of breath, to respiratory failure. The correct diagnosis by histopathological examination supplemented by immunohistochemistry tests involves the establishment of a treatment in the early stages and thus a favorable prognosis [6]. Immunohistochemical tests can highlight the interaction between the local and general changes of diseases [7].

Analyzing the results of immunohistochemistry investigations, the histological type and the localization of T-cell NHL manifestations, we present our studies regarding $T$ cell lymphoma with first oral manifestation and we detailed the an extremely rare case of a patient with a peripheral T cell lymphoma, which had the first manifestation in the Waldeyer ring area at the level of the palatine tonsils.

\section{Experimental part \\ Material and methods}

The researches were realized in Dental Medicine Faculty and Emergency Clinical Hospital of Tirgu Mures, between the periods of 2014-2016. The included patients in the research (19, 9 male and 10 female) were grouped on age in two groups, 40-65 years (7 patients) and 66-91 years (12 patients). The histopathological tests were processed at the Pathological Anatomy Department of the County Emergency Clinical Hospital for the specified 3 years. We included in our study only NHL that presented first manifestations in the oral, maxillary, facial and the neck area.
We detailed an extremely rare case of a patient with a peripheral T cell lymphoma, which had the first manifestation in the Waldeyer's tonsillar ring area, at the level of the palatine tonsils. The female patient of 57 years old, from urban area, experienced repeated and abundant bleeding in the mouth as first clinical manifestation. The patient had multiple presentations at the dental services (Department of Oro-Maxilo-Facial Surgery) and E.N.T. Department of the County Emergency Clinical Hospital in Tirgu-Mures due to repeated and rebel at treatment oral bleeding. Upon hospitalization, the patient presents deglutition disorders for solids and liquids, frequentbleeding in the mouth (fresh blood), inspiratory dyspnea, snoring, obstructive sleep apnea, feverish. The objective examination shows pale turgid face, bilateral cervical polyadenopathy with multiple mobile nodules (between 1.5 - $4 \mathrm{~cm}$ diameters) of the elastic consistency, slightly sensitive to palpation. The examination of oral mucosa shows hyperemic mucosa, coated tongue, asymmetric hypertrophic palatine tonsils much enlarged (right tonsil approx. $5.5 / 3.5 / 2 \mathrm{~cm}$ and left tonsil approx. $4.5 / 2 / 1.5 \mathrm{~cm}$ ), united on the median line, with bleeding and whitish deposits on the surface. Anterior and posterior rhinoscopy was without pathological changes, with free larynx, and frees vocal cords. The patient's feverish state, as well as the aspect of the palatine tonsils required the examination at the Contagious Diseases Department, where the infectious as mononucleosis and toxoplasmosis are excluded, rising the suspicion of infection with Chlamydia. Laboratory examinations show the following changes: ESR: $40 \mathrm{~mm} / 1$ h, CRP: 45, 84mg/L, Ac IgG anti Chlamydia Pneumoniae: 1.78-positive, the other hematologic examinations were normal. The patient followed treatment with antibiotics and with haemostasis medication. After 7 days, the overall state improved and the patient did not have fever, but she still experienced functional disorders (dysphagia and dyspnea) caused by tonsils hypertrophy. It was decided bilateral tonsillectomy for necessity and for diagnosis purposes too (histopathological examination of the palatine tonsils), after an adequate preoperative preparation. The pieces specimens were fixed in 10\% buffered formalin. Macroscopically, the tonsils surfaces presented ulceration areas, and on the section, the cryptic structure faded, with homogeneous, solid, grayish aspect. Palatine tonsils were examined at the Pathological

* email: galoltean@yahoo.com 
Anatomy Department of the County Emergency Clinical Hospital in Tirgu Mures, and there was founded a suspicion of hematological tumor disorder.

\section{Results and discussions}

In the period 2014-2016, we found a total of 19 patients which presented lymphomas with manifestations in the oral, maxillofacial and the neck area. Of these, 9 were men $(47.36 \%)$ and 10 women (52.63\%), ascertaining an almostequal distribution.

The results of study show a higher frequency of lymphomas in the second age group (between 66-91 years, 12 patients $=63.16 \%$ ). In our studies, out of a total of 19 patients suffering of $\mathrm{NHL}$, we found one case (5.26\%) of peripheral T-cell lymphoma, the most common being the diffuse lymphomas with large cells (94.73\%).

The locations of the studied lymphomas were at the level of the palatine tonsils in 6 cases (31.58\%), at the level of the epipharynx in 5 cases (26.32\%), followed by the localization in oropharynx ( 2 cases $=10.52 \%$ ), in roof of the mouth ( 2 cases $=10.52 \%$ ), in the area of maxillary tuberosity ( 2 cases $=10.52 \%$ ) and in the area of the pharynx/larynx ( 1 case $=5.26 \%$ ) and tongue tonsil ( 1 case $=5.26 \%)$ (table 1$)$.

Table 1

THE LOCATIONS OF THE STUDIED LYMPHOMAS

\begin{tabular}{||l|c|c||}
\hline \multicolumn{1}{|c|}{ Locations } & Cases number & Percentage \\
\hline \hline Palatine tonsils & 6 & $31.58 \%$ \\
\hline Epipharynx & 5 & $26.32 \%$ \\
\hline Oropharynx & 2 & $10.52 \%$ \\
\hline Roof of the mouth & 2 & $10.52 \%$ \\
\hline Maxillary tuberosity & 2 & $10.52 \%$ \\
\hline Pharynx/larynx & 1 & $5.26 \%$ \\
\hline Tongue tonsil & 1 & $5.26 \%$ \\
\hline
\end{tabular}

From a histological point of view, the diffuse lymphomas with large B-cells accounted for $78.95 \%$ ( 15 cases), and the other lymphomas were represented by a case of plasmoblastic lymphoma (5.26\%), a case of follicular ymphoma grade $2(5.26 \%)$, a case of mantle cell lymphoma (5.26\%) and a case of peripheral T-cell lymphoma (5.26\%) (table 2 ).

\section{Table 2}

THE TYPE OF STUDIED LYMPHOMAS AFTER THE HISTOLOGICAL EXAMINATION

\begin{tabular}{||l|c|c||}
\hline \multicolumn{1}{|c|}{ Locations } & Cases number & Percentage \\
\hline \hline Diffuse lymphomas with large B-cells & 15 & $78.95 \%$ \\
\hline Plasmoblastic lymphoma & 1 & $5.26 \%$ \\
\hline Follicular lymphoma grade 2 & 1 & $5.26 \%$ \\
\hline Mantle cell lymphoma & 1 & $5.26 \%$ \\
\hline Peripheral T-cell lymphoma & 1 & $5.26 \%$ \\
\hline
\end{tabular}

In the presented case, the structure of the tonsils, from microscopically point of view, was completely faded in the inter-cryptical area (fig. 1.), being expanded by a proliferation of lymphoid cells with polymorph aspect, presenting predominantly medium and large cells, with vesicular nuclei, with prominent nuclei, other hyperchromatic, with numerous mitoses.

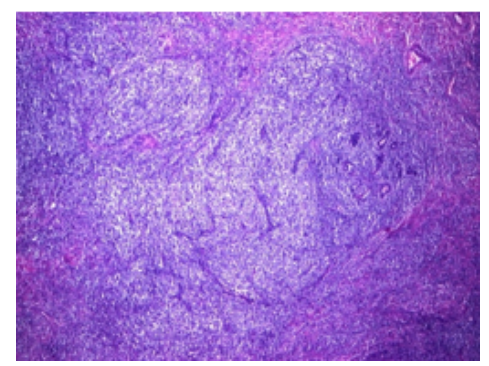

Fig. 1. Tonsil structure obstructed by a lymphoid infiltration with a nodular distribution

(Hematoxiline eosine $\mathrm{E}, \mathrm{x} 2$ )
Some of the cells were multinucleated giant cells resembling Sternberg Reed cell (fig. 2). The distribution of lymphoid cells has a nodular characteristic, but focally, one may notice a paracortical expansion of the lymphoid infiltrate. The surrounding stroma of these cells contains numerous small lymphocytes, plasma cells and eosinophils.

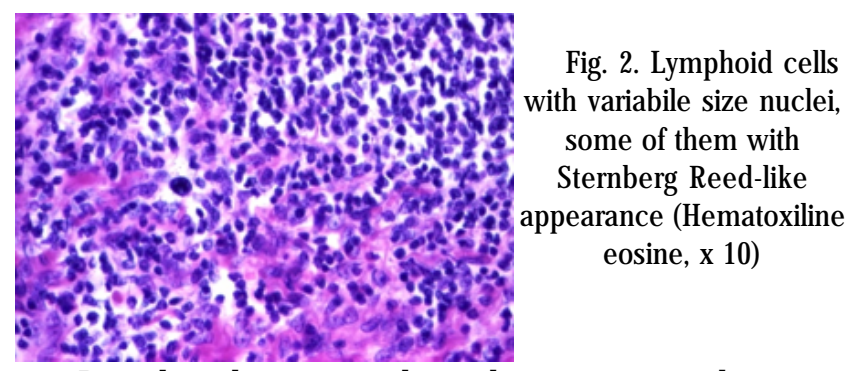

Based on the immunohistochemistry tests, the tumor cells are positive at $C D$ 3, (fig. 3), 5 CD (fig. 4) and $4 C D$ (fig. 5).

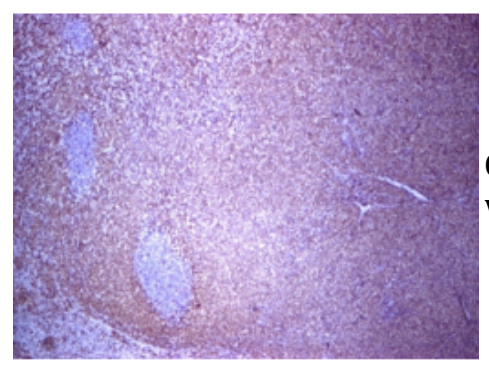

Fig. 3. Immunostaning for CD 3, which shows positivity with paracortical distribution

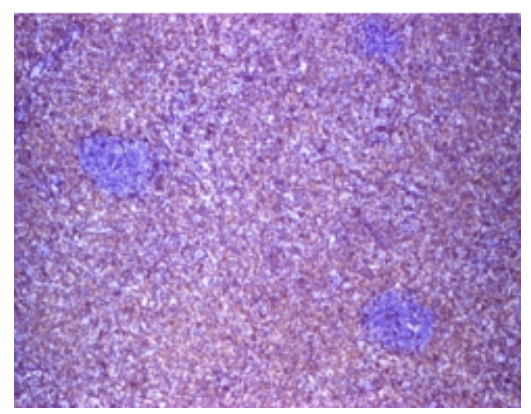

Fig. 4. T cell positive for CD 5

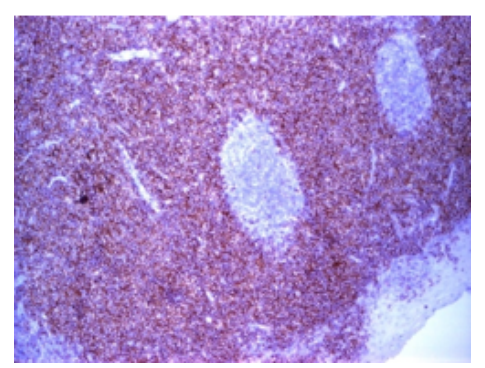

Fig. 5. T cell positive for CD 4

Other $T$ cell markers were negative, like $C D 7$ and $C D$ 8 , and also $B$ cell markers CD 20 (fig. 6) and pax 5. Imunostains for CD 30, CD 56, CD 10, CD 1, Tdt were negative. The proliferation index ki 67 is about $50 \%$ (fig. 7).

As a result of the histopathological and immunohistochemical examinations of the tonsil biopsy, the diagnosis of peripheral T-cell lymphoma was established. The patient is subjected to an overall examination in order

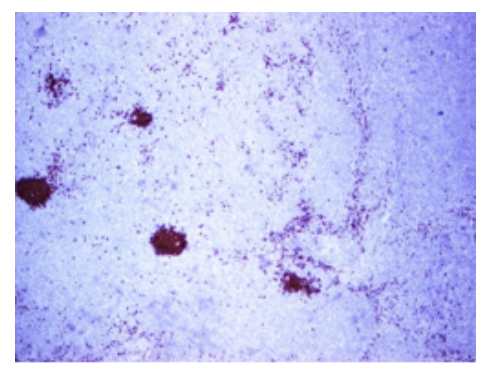

Fig. 6. B cell positive for $C D 20$ in the remaining follicles 
Fig. 7. Proliferation index for ki 67 aprox 50\%

to start the treatment. The virus balance detects the infection with human Tlymphotrophic virus 1 HTLV-1, other results $\mathrm{LDH}=472 \mathrm{u} / \mathrm{l}, \mathrm{Ca}=8.9 \mathrm{mg} / \mathrm{dL}$, Le $=16600 \mathrm{~mm}^{3}$, $\mathrm{S}=90 \%, \mathrm{Li}=2 \%, \mathrm{Tr}=181000 / \mathrm{mm}^{3}$, the osteomedular biopsy being free of disease infiltrate. CT shows lesions with disease aspect in the bilateral parotid, in the pulmonary areas, in the fat of the right paramedian abdominal wall, $1 / 2$ inferior left kidney, lateral - cervical adenopathy, under the mandible, below $1 \mathrm{~cm}$, mediastinal adenopathies up to 2$3 \mathrm{~cm}$ on upper and middle level and, below the carina, conglomerates of $4.5 \mathrm{~cm}$. The pulmonary hilum presented bilateral lymph nodes of $3.5 \mathrm{~cm}$ and the left bronchopulmonary, conglomerates of $5.3 \mathrm{~cm}$. The final diagnosis was established according the histopathological, serological and clinical examination, as a variant of peripheral type T cell lymphoma, associated with HTLV 1 virus, adult T cell lymphoma/leukemia (ATL/L) lymphomatous form, without leukemia.

The treatment was carried out according to protocol LSG-15, 7 cures and Intrathecal administrations. After finishing Protocol LSG-15 [8], a new clinical - biological assessment is made in order to prepare the patient for bone marrow transplant. In the presented case, after finishing seven cures of chemotherapy, the patient's biological condition improved greatly. The results are: CT without adenopathies, spleen $11 / 12.5 \mathrm{~cm}$ and liver with the cranial-caudal diameter of $15.5 \mathrm{~cm}$, brain MRI without modifications. We decided to start the preparation for bone marrow transplant because of a much better prognosis in the case combining the two treatment types. Between 01.02-08.03. 2017, the patient was admitted to Fundeni IC for bone marrow transplant. Post transplantion, the patient's condition at the examinations of 40 and 55 days is good, fever free, cardio-respiratory balanced.

Literature data show that survival rates in patients with T-cell lymphoma is of $45 \%$ in the case of combining chemotherapy with allopathic transplant compared to $25 \%$ survival rates in patients who follow only chemotherapy treatment $[8,9]$.

The histopathological classification of lymphomas caused over de years discontent of both clinicians and pathologists. In 2017, the International Lymphoma group proposed a new revised European-American classification of lymphoid neoplasms in an attempt to provide the best information's regarding disease biology, natural history and response to treatment [10]. They concluded that the best way to classify these tumors is to define the disease that we think we can recognize with the currently available morphological, immunological and genetic tools. Also they include in the same classification of the lymphomas and leukemias because both solid and circulating phases are present in many lymphoid neoplasms. T cell and putative NK-cell lymphomas was classified in two categories: precursor T cell lymphoma and peripheral T cell and NK cell neoplasm. Four subtypes of peripheral T cell lymphoma were considered to have different features recognizable by the pathologists: angioimmunoblastic T cell lymphoma, angiocentric lymphoma, intestinal $\mathrm{T}$ cell lymphoma and adult T cell lymphoma/leukemia (HTLV1+). Adult T-cell Lymphoma/Leukemia (ATL/L) is defined as a T-cell neoplasm caused by HTLV1 [6,10].

The histology of these diseases are variable. The pattern in lymph nodes is diffuse and usually appear like a mixture of small, medium and large atypical cells with pronounced polymorphism and nuclear pleomorphism [11]. Tumor cells express T-cell-associated antigens (CD2,3,5+) but usually lack CD7. The most are CD4+ CD25+ and rare CD8+ cases have been reported. After genetic features, TCR genes are clonally rearranged $[12,13]$. The majority of patients are adults, who have antibodies to HTLV1. Most cases occur in Japan, but an endemic focus is found in the Caribbean, sporadic cases are found in the United States and several clinical variants have been described $[10,14]$. Most common is the acute form, which presents with a high white blood cell count, hepato-splenomegaly, hypercalcemia, and lytic bone lesions, with median survival less than 1 year [15]. The rare lymphomatous form is characterized by isolated lympha-denopathy without leukemia [16]. A chronic form with lower white blood cell count, withouthypercalcemia or hepatosplenomegaly, has slightly longer survival, and rare smoldering cases have mild lymphocytosis, which is demonstrably clonal, but very indolent course. Both chronic and smoldering forms often have skin rashes $[10,17]$.

After the studies of Papuc and al [18], free radicals and antioxidant activities of plants during cancer treatments can reduce the side effects of chemotherapy. A comprehensive study conducted on a 41-year period showed that the rate of 2-3\% of extranodal non-Hodgkin lymphomas show manifestations in the mouth [19]. The most recent studies related to extranodal NHL in the head and neck show that the most common locations were at the salivary gland level $41 \%$, at the level of mandible and cheek bone $41 \%$, and the remaining percentages were distributed in the para-nasal sinuses, orbit and Waldeyer lymph ring $[3,14]$. The studies on $122 \mathrm{NHL}$ with manifestations in the head and neck have described one case with manifestations in the oral cavity $[3,14,20]$. Statistical data from the literature show a frequency of Tcell NHL between $10-12 \%$ of NHL, ranging from $1.5 \%$ in Canada, Vancouver and British Colombia, 18.3\% in Hong Kong. This variation is given by the greater incidence of HTLV infection (adult T-cell leukemia virus) and Epstein Barr virus in Asian countries. Of the possible etiologic factors, we mention: exposure to physical or chemical mutagens, abnormalities of immune adjustments (hereditary or induced) or specific viral infections [21,22]. Between 1992 and 2001, SEER reported in the U.S.A. a higher incidence of neoplasias T/NK of $1.77 / 100000$ inhabitants/year [23,24]. Long time studies are needed to discover the mechanisms underlying these apoptotic effects [25]. Regardless of the method of treatment, patient's monitoring / controls is mandatory, considering the risk of recurrence [26].

\section{Conclusions}

The rarity of the cases of peripheral T-cell lymphoma located in the oral cavity involves the need for carefully realized complex examinations.

Considering the severe prognosis of malignant lymphopathies and especially the T-cell lymphomas, the early correct diagnosis is essential.

The importance of the correct diagnosis of peripheral Tcell lymphoma located in the oral cavity, in the terms of histopathological and of immunohistochemical tests, is reflected in the establishing and in the conducting of the adequate therapy for a favorable prognosis. 


\section{References}

1.SALPLAHTA D, COMANESCU MV, ANGHELINA F, IONITA E, MOGOANTA CA, ANGHELINA L. Rom J Morphol

Embryol. 2012;53:1057-60

2.ZADIK Y, LEHMAN H, NEUMAN T, BENOLIEL R. Quintessence Int. 2012;43:769-75

3.TRIANTAFILLIDOU K, DIMITRAKOPOULOS J, IORDANIDIS F, GKAGKALISA. J Oral Maxillofac Surg. 2012;70:2776-85

4.*** https://www.ncbi.nlm.nih.gov/pubmedhealth/PMH0032836/

5.LAGE LA de PC, CABRAL TC dos S, COSTA R de 0, et al, Revista Brasileira de Hematologia e Hemoterapia, 2015, 37(4):277-284

6.JAFFE E, BLATTNER W, BLAYNEY D, BUNN P,COSSMAN J, ROBERTGUROFF M, GALLO R, Am I Surg Pathol 8:263, 1984

7.CHICEA, R, BRATU, D, CHICEA, AL, MIHETIU, A, PRELUCA, V, TANTAR, C, SAVA, M, Mat. Plast., 54, no. 3, 2017. p. 510-512

8.TSUKASAKI K., UTSUNOMIYA A., FUKUDA H., SHIBATA T., FUKUSHIMA T., TAKATSUKA Y., IKEDA S., MASUDA M., NAGOSHI H., UEDA R., et al., Japan Clinical Oncology Group Study JCOG9801. J. Clin. Oncol. 2007;25:5458-5464

9.HISHIZAWA M., KANDA J., UTSUNOMIYA A., TANIGUCHI S., ETO T., MORIUCHI Y., TANOSAKI R., KAWANO F., MIYAZAKI Y., MASUDA M., et al., Blood. 2010;116:1369-1376. doi: 10.1182/blood-2009-10-247510 10.HARRIS NL, JAFFE ES, STEIN H, BANKS PM, CHAN JK, CLEARY ML, DELSOL G, DE WOLF- PEETERS C, FALINI B, GATTER KC., Blood 1994, 84: 1361-1392

11.ABDELWAHED HUSSEIN MZ, Expert Rev Hematol. 2013;6(2):139153

12. VASILE D, VLADAREANU A-M, BUMBEA H.. Mædica. 2014;9(1):104108

13.*** http://www.lymphoma.org
14.MELO J, CATOVSKY D, GALTON D., Br J Haematol, 1985, 63:377 15.GRAHAM RL, BURCH M, KRAUSE JR., Proceedings (Baylor University Medical Center), 2014;27(3):235-238

16.GUERMAZI A., Radiological Imaging in Hematological Malignancies, Springer-Verlag Berlin, 2004, pp. 217-218

17.KUNNATHUPARAMBIL SG, PAYANGAPPADOM PK, YEROL PK, et al., Annals of Gastroenterology. 2012;25(2):170-172

18.PAPUC, C, CRIVINEANU, M, GORAN, G, NICORESCU, V, DURDUN, N, ev. Chim. (Bucharest), 61, no.7, 2010, p. 619-622

19.SILVA TDB, FERREIRA CBT, LEITE GB, DE MENEZES PONTES JR, ANTUNESHS, ecancermedicalscience, 2016;10:665

20.IGUCHI H, WADA T, MATSUSHITA N, OISHI M, YAMANE H., Acta Otolaryngol. 2012;132:1224-31

21.WALTER C, ZIEBART T, SAGHEB K, RAHIMI-NEDJAT RK, MANZ A, HESS G., IntJ Med Sci, 2015; 12(2):141-145

22.KINPARA S., KIJ IYAMA M., TAKAMORI A., HASEGAWA A., SASADA A., MASUDA T., TANAKA Y., UTSUNOMIYA A., KANNAG M., Retrovirology. 2013;10:52

23.DE OLIVEIRAFERREIRA J M , KLUMB CE, DE SOUZAREIS R, DE OLIVEIRASANTOS M, PINTOOLIVEIRA JF, DE CAMARGO B, POMBODE-OLIVEIRA MS, Cancer Epidemiology, Vol. 36, No. 4, August 2012, Pages e221-e226

24.CHIHARA D, NASTOUPIL LJ, WILLIAMS JN, LEE P, KOFF JL, FLOWERS CR., 2015;15(5):531-544

25.ACATRINEI, D, GENTIMIR (AMITITELOAIE), C, ZAHARIA (AVRAM), C, RADUCANU, C.0, BOGZA, G, CHELARU, L, VASINCU, D., BOISTEANU, 0, COSTULEANU, M., Rev. Chim.(Bucharest), 67, no.1, 2016, p. 57-60

26.COSARCA, A.S, GRIGORAS, R, HANCU, V, COMAN, C, COMANEANU, R.M, MORARU, L, TARCOLEA, M, ORMENISAN, A, Mat. Plast., 53, no.1, 2016, p. 135-138

$\overline{\text { Manuscript received: } 26.04 .2018}$ 